Primljen / Received: 29.2.2016 Ispravljen / Corrected: 30.5.2017

Prihvaćen / Accepted: 27.11.2017.

Dostupno online / Available online: 10.6.2019.

\section{Laboratory studies into hydraulic coefficient in curved planform labyrinth weir and piano key weir}

1,2Behzad Zeraat, PhD. CE b.zeraat@yahoo.com

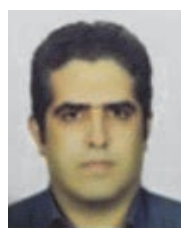

${ }^{2}$ Assist.Prof.MohammadHeidarnejad mo_he3197@yahoo.com

${ }^{2}$ Assoc.Prof. Alireza Masjedi drmasjedi.2007@yahoo.com

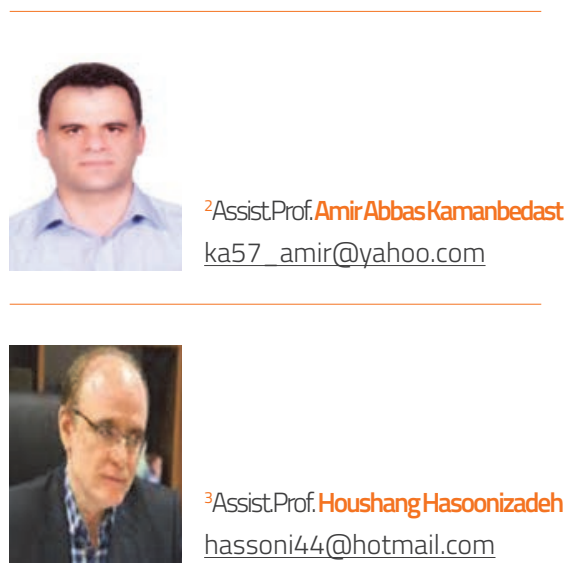

${ }^{1}$ Department of Water Science Engineering Khouzestan Science and Research Branch Islamic Azad University, Ahvaz Iran

${ }^{2}$ Department of Water Science Engineering Ahvaz Branch, Islamic Azad University Ahvaz Iran

${ }^{3}$ Iran's Khuzestan Water and Power Authority
Professional paper

Behzad Zeraat, Mohammad Heidarnejad, Alireza Masjedi, Amir Abbas Kamanbedast,

Houshang Hasoonizadeh

\section{Laboratory studies into hydraulic coefficient in curved planform labyrinth weir and piano key weir}

In this paper, the discharge coefficient of piano key weirs is compared with that of curved planform labyrinth weirs. Results show that the discharge coefficient of piano key weirs is by $17.1 \%$ higher compared to that of curved planform labyrinth weirs. The difference in discharge coefficient of these two weirs reduces with an increase in hydraulic load and attainment of submerged discharge, when both weirs exhibit similar results.

Key words:

labyrinth weir, curved planform weir, piano key weir, discharge coefficient

Stručni rad

Behzad Zeraat, Mohammad Heidarnejad, Alireza Masjedi, Amir Abbas Kamanbedast,

Houshang Hasoonizadeh

\section{Laboratorijska analiza hidrauličkog koeficijenta labirintskog preljeva zakrivljenog tlocrta i tipkastog preljeva}

U radu se koeficijent otjecanja tipkastih preljeva uspoređuje s odgovarajućim koeficijentom otjecanja labirintskih preljeva zakrivljenog tlocrta. Rezultati pokazuju da je koeficijent otjecanja tipkastih preljeva za 17,1\% veći od koeficijenta otjecanja labirintskih preljeva zakrivljenog tlocrta. Razlika u koeficijentu otjecanja tih dvaju preljeva smanjuje se povećanjem hidrauličkog opterećenja i postizanjem potopljenog otjecanja, kada su dobiveni podjednaki rezultati za obje vrste preljeva.

Ključne riječi:

labirintski preljev, preljev zakrivljenog tlocrta, tipkasti preljev, koeficijent otjecanja

Fachbericht

Behzad Zeraat, Mohammad Heidarnejad, Alireza Masjedi, Amir Abbas Kamanbedast, Houshang Hasoonizadeh

\section{Laboruntersuchungen zum hydraulischen Koeffizienten im gekrümmten Labyrinth- und Pianoschlüsselwehr}

In der Abhandlung wird der Abflusskoeffizient des typischen Überlaufs mit dem entsprechenden Abflusskoeffizient des labyrinthischen Überlaufs mit gekrümmtem Grundriss verglichen. Die Ergebnisse zeigen, dass der Abflusskoeffizient des typischen Überlaufs um 17,1\% höher ist, als der Abflusskoeffizient des labyrinthischen Abflusses mit gekrümmtem Grundriss. Der Unterschied bei den Abflusskoeffizienten dieser beiden Überläufe verringert sich mit der Erhöhung der hydraulischen Belastung und dem Erzielen eines Sinkabflusses, wenn man gleiche Ergebnisse für beide Überlaufarten erhält.

Schlüsselwörter:

labyrinthischer Überlauf, Überlauf mit gekrümmtem Grundriss, typischer Überlauf, Abflusskoeffizient 


\section{Introduction}

Weirs are classified among structures for the measurement and regulation of the volume rate of water flow. One of the main reasons for dam failure is an insufficient weir discharge capacity, which is why weirs with high discharge capacity should be designed. The application of labyrinth weirs is well known as an effective and economical solution for increasing the discharge rate. These weirs expand the release capacity further than linear weirs for a similar hydraulic load through elongation of a crest within a certain width. At the flood peak, the overflow discharge reaches a maximum value in a short time; therefore, a weir with a high discharge coefficient seems essential. To this end, labyrinth weirs with the discharge coefficient larger than that of linear weirs are used [1]. The PKWs, as weirs with very high discharge capacity, are efficient and cost-effective structures.

Just like labyrinth weirs, PKWs have a curved planform that makes them capable of increasing discharge capacity within a certain weir channel width. These structures are a good solution for meeting needs of dam construction projects, i.e. to increase discharge capacity or decrease the flood discharge crosssectional area (Figure 1).

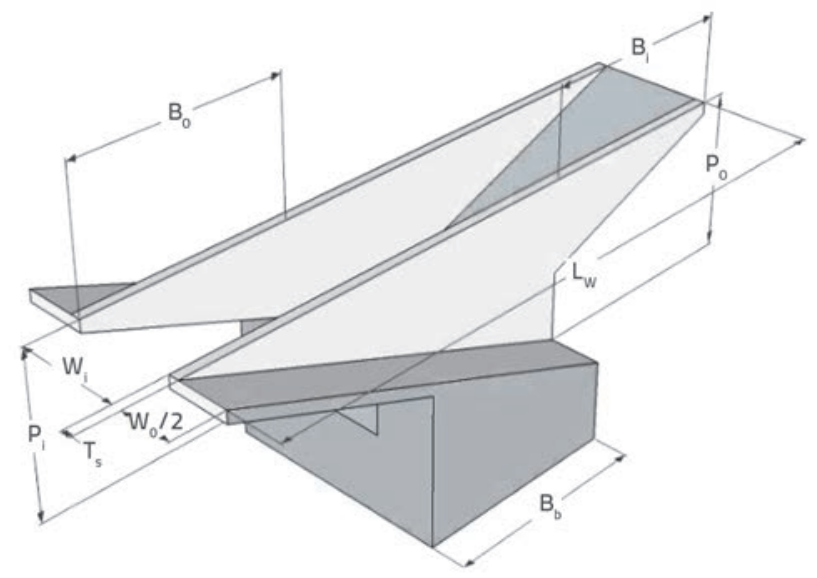

Figure 1. Schematic illustration of piano key weir (PKW)

Important parameters of a given PKW (Figure 1) are as follows: $\mathrm{Po}$ is the outlet key height of the weir, $\mathrm{Pi}$ is the inlet key height of the weir, $W$ is the weir width, $B$ is the weir length, $\mathrm{Bo}$ is the outlet key length, $\mathrm{Bi}$ is the inlet key length, Wi is the inlet key width, Wo is the outlet key width, and Ts is the wall thickness.

The application of these types of weirs increases the water flow volume rate. Thus, it is necessary to lower free upstream head as compared to linear weirs. It has to be noted that in cases when weirs are used as flood discharge controlling structures they also facilitate the flood routing [2].

The early studies by Hay and Taylor (1970) show that the performance of labyrinth weirs is independent of W/P ratio, where $\mathrm{W}$ and $\mathrm{P}$ stand for the cycle width and weir height, respectively [3]. Complementary studies by Falvey [1] show that if the W/P ratio is below a certain level, it will have a significant effect on the reduction of weir efficacy.

The first PKW was constructed in 2006 at Goulours Dam in France [4]. During 2008-2010, PKWs were used to improve flood discharge at several dams such as Mark Saint, Etroit, and Goulours. Laboratory studies by Ouamane and Lempérière [5] showed two dominant flow types in PKWs as follows: The inlet key attracts the approach flows, and similar to sharp-crested weirs with the sloped sidewall, nappe flow discharges into downstream over the inlet crest. The second pattern is formed on the outlet keys, in that the outlet crest jet flow discharges into the downstream of the sloped discharge key [5].

Leite Riberio et al. [6] used the results of existing physical models to develop a general equation for PKW's the dischargestage relationship. According to their findings, the capacity of such a weir is dominantly influenced by the head of water over the weir, overall length, the inlet key height, and the transverse width.

Machiels (2012) reported the positive effect of parapet wall on hydraulic performance of such weirs through approaching weir height to optimal height [7].

Crookston and Tullis $([8,9]$ investigated characteristics of nappe Interference and local submergence in triangular labyrinth side weirs with two and four cycles and different apex angles on a laboratory scale. Results show that at low discharge rates, the discharge coefficient is larger compared to the linear weir (due to small nappe interference) and the interference intensity gradually increases with an increase in discharge. Accordingly, the discharge coefficient reduces and becomes almost equal to that of a broad-crested weir.

Anderson and Tullis [10] compared hydraulic performance of labyrinth weirs and rectangular PKWs and showed a better performance of PKWs due to loss reduction in inlet keys.

In addition, Anderson and Tullis [11] compared performance of PKWs in the inlet key to outlet key ratios from 0.67 to 1.5 and concluded that the discharge coefficient increases with an increase in Wi/Wo (inlet key width to outlet key width). Cd is the discharge coefficient, $\mathrm{Ht}$ is the head over a weir, and $\mathrm{p}$ stands for weir height.

Javaheri and Kabirisamani [12] performed several studies on 20 geometrically different laboratory models to determine the effect of geometric and hydraulic parameters on PKW discharge. They investigated the impact of effective geometric parameters including weir length, weir height, and inlet and outlet widths on PKW's discharge coefficient. They finally proposed Eq. (1) with the least error rate as the best equation for determination of the weir discharge coefficient at free flow condition, using the general equation of weirs. 
$C d=\left(0.212\left(\frac{H}{P}\right)^{-0.075} \cdot\left(\frac{L}{W}\right)^{0.377} \cdot\left(\frac{W_{i}}{W_{0}}\right)^{0.426} \cdot\left(\frac{B}{P}\right)^{0.036} \cdot \operatorname{EXP}\left(1.504 \frac{B_{0}}{B}+0.093 \frac{B_{i}}{B_{0}}\right)\right)+0.606(1)$

Karimi-Chahartaghi et al. [13] studied the effect of the variable crest at angles $0^{\circ}$ and $10^{\circ}$ on the discharge coefficient and discharge-stage curve of a PKW physical model. Using the general equation for weirs, they finally estimated the discharge coefficient values as being about 1.76 at the crest angle of $0^{\circ}$, and almost 6.13 at the crest angle of $10^{\circ}$. Results indicate that a minor change in weir crest increases the discharge coefficient by 3.5 times, which is economically efficient.

Heidarpoor et al. [14] conducted a laboratory study to investigate condition of one-cycle labyrinth weirs with a rectangular and $\mathrm{U}$-shaped plan. The results suggested that the discharge coefficient within a certain Ho/P (the ratio of overall upstream energy to weir height) increases with an increase in weir height. In addition, comparisons showed that elongation across flow direction in labyrinth weirs reduces the discharge coefficient, whereas an elongation perpendicular to flow directsion increases the discharge coefficient.

Although there are some studies on the performance of PKWs, few of them have compared the discharge coefficient in PKWS with labyrinth weirs with curved planform. Hence, this study addresses discharge coefficient in PKW and compares it with discharge coefficient in a two-cycle labyrinth weir with curved planform.

\subsection{Dimensional analysis}

As shown in Figures 1 and 2, important geometric parameters in PKW design are weir height $(\mathrm{P})$, height of crest to center of sloped floor $\left(P_{m}\right)$, crest centerline length $(\mathrm{L})$, slope of the inlet key $\left(\mathrm{S}_{\mathrm{i}}\right)$ and outlet key $\left(\mathrm{S}_{0}\right)$ floors, weir width $(W)$, weir length $\left(B_{b}\right)$, outlet key length $\left(B_{0}\right)$, inlet key length $\left(B_{i}\right)$, inlet key width $\left(W_{i}\right)$, outlet key width $\left(W_{0}\right)$, wall thickness $\left(T_{s}\right)$, overall key width ( $W$; where $\left.W=W_{i}+W_{o}-T_{s}\right)$, and number of keys (N).

Important geometric ratios in PKW design include the weir crest length over the weir width $(n=L / W)$, inlet over outlet weir lengths $\left(\mathrm{B}_{\mathrm{i}} / \mathrm{B}_{0}\right)$, inlet key over outlet key widths $\left(\mathrm{W}_{\mathrm{i}} / \mathrm{W}_{0}\right)$, and wall thickness to weir height $\left(T_{s} / P\right)$.

According to previous studies, factors affecting performance of labyrinth weirs with curved planform are: geometric parameters including weir width, crest length, height of crest above the upstream floor, length of apex's inner face, and angle of weir wall to main flow direction; structural configurations including crest shape, presence of aprons, and weir walls thickness; exploitation conditions including overall hydraulic loading, and different stages of weir submergence, and de-aeration; downstream conditions including crest height, water depth, sloped or non-sloped downstream; and upstream conditions including inlet conditions, shape of guide wall, sloped and non-sloped upstream [15].

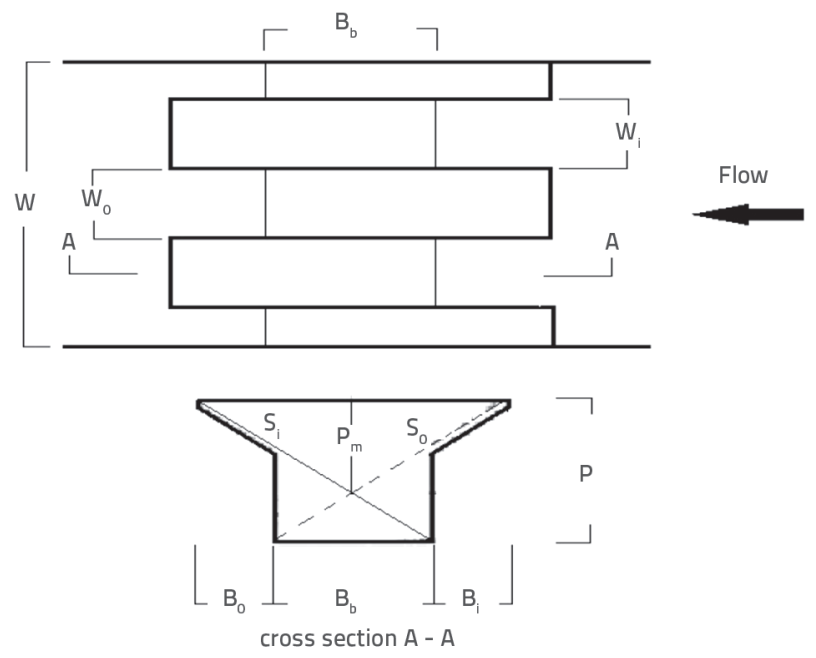

Figure 2. Important geometric parameters in PKW design

It is very difficult to describe the 3D flow in labyrinth weirs. To deal with such complexity a mathematical equation is needed to take into account the energy, momentum, and continuity equations, along with parameters such as the weir geometry, crest shape, local submergence, interference of flow layers over a weir, non-parallel flow lines, pressure under nappe, presence or absence of an air pocket behind nappe, effects of surface tension, and viscosity. The general weir equation introduced by Tullis et al. (1995) was used for labyrinth weirs [16]:

$Q=\frac{2}{3} C_{d} L \sqrt{2 g} H_{0}^{1.5}$

where $Q$ is the weir discharge $\left(\mathrm{m}^{3} / \mathrm{s}\right)$, $\mathrm{L}$ is the length $(\mathrm{m})$ (like the length of weir), $g$ is the acceleration of gravity $\left(\mathrm{m} / \mathrm{s}^{2}\right)$, Ho is the overall hydraulic load $(\mathrm{m})$, and $\mathrm{C}_{d}$ is the dimensionless discharge coefficient determined by laboratory tests.

In general, effective hydraulic quantities in PKWs are presented as follows:

$\eta=f\left(Q, B_{i^{\prime}} B_{o^{\prime}} S_{i^{\prime}} S o_{o^{\prime}} t, p, D, W, n, H o, H_{d^{\prime}} S_{e^{\prime}} S, Y, V, g, \mu, \rho, v, \sigma\right)$

where $Q$ is the channel discharge $\left(\mathrm{m}^{3} / \mathrm{s}\right), B_{i}$ is the inlet key width $(m), B_{0}$ is the outlet key width (m), $Y$ is the depth of flow in channel $(\mathrm{m}), \mathrm{V}$ is the velocity of flow in channel $(\mathrm{m} / \mathrm{s}), \mathrm{g}$ is the acceleration of gravity $\left(\mathrm{m} / \mathrm{s}^{2}\right), \mu$ is the dynamic viscosity or fluid density (pa.s), $t$ is the thickness of weir wall $(m), U$ is the kinematic viscosity $\left(\mathrm{m}^{2} / \mathrm{s}\right), \mathrm{S}$ is the inlet key slope, $\mathrm{S}_{0}$ is the outlet key slope, $\mathrm{D}$ is the weir height in downstream (m), $\mathrm{p}$ is the weir height in upstream $(m), w$ is the cycle width $(m), n$ is the cycle number, $\sigma$ is the surface tension (pa), $\mathrm{HO}$ is the overall hydraulic loading on upstream $\mathrm{m}$ ), $H_{d}$ is the overall hydraulic loading in downstream (m), $S$ is the channel slope, $W$ is the channel width $(\mathrm{m})$, and $\mathrm{S}_{\mathrm{e}}$ is the factor determining the shape of crest cross-section.

$C_{d}=f\left(B_{i} / P, B_{0} / P, B / P, S_{i}, S_{0^{\prime}} T s / P, D / P, w / P, N, S e, H_{t} / P, H_{d} / P, S\right.$, $\left.\mathrm{gP}^{5} / \mathrm{Q}^{2}, \mu \mathrm{P} / \rho \mathrm{Q}, \mathrm{w}_{\mathrm{i}} / \mathrm{P}, \mathrm{w}_{\mathrm{o}} / \mathrm{P}, \sigma / \rho \mathrm{VP}\right)$ 


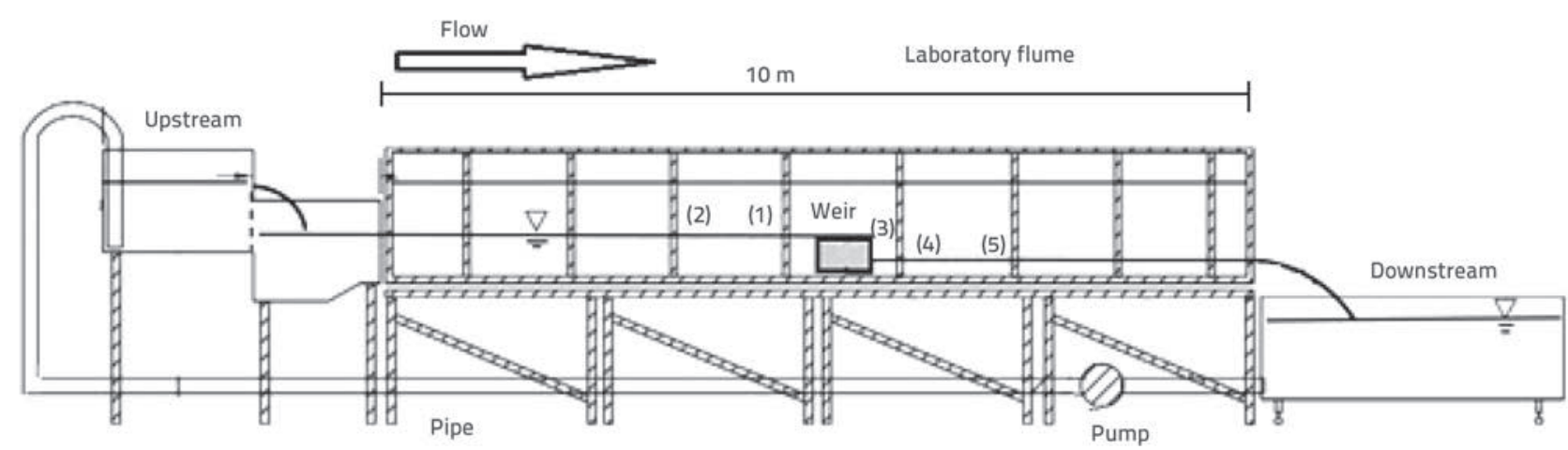

Figure 3. General layout of laboratory flume $(1,2,3,4$, and 5 are water depth measuring points)

In this study, So, Si, Bi, Bo, $g, \mu, \rho, T s, v, w, W, n, \sigma, S, B$, and Se are constant parameters and $\mathrm{P}$ equals $\mathrm{D}$. Flow velocity and water depth on weir show that the Reynolds number is in the range of turbulence. Moreover, the Weber number in experiments indicates that surface tension is lower than kinetic energy and, actually, the experiments are not affected by surface tension. Considering different hydraulic loads for $\mathrm{Ho} / \mathrm{P}<0.06$ ratio, since the jet passing over the weir remains in direct contact with the crest, the discharge coefficient is affected by surface tension. Thus, according to their studies and based on the following relation, the Weber number in $\mathrm{Ho} / \mathrm{P}<0.06$ ratio is less than 50 [7].

$w e=\frac{\rho V^{2} H}{\sigma}$

After dimensional analysis and removal of fixed parameters, the effect of hydraulic head on the discharge coefficient with curved planform Labyrinth weir and PKW is studied at three different heights using the following equation:

$$
C_{d=} F(H o / P, w / P)
$$

\section{Materials and methods}

In this work, the hydraulic analyses of PK and CLW are compared by recording the flow depth and velocity at the upstream and downstream and by measuring discharge.

In this study, laboratory experiments were conducted using a laboratory flume in the Hydraulic Laboratory of the Water and Electricity Organization of Khuzestan in Iran. The laboratory weir models were examined in a rectangular free-flow flume with the length, width, and depth of $10 \mathrm{~m}, 0.3 \mathrm{~m}$, and $0.6 \mathrm{~m}$, respectively. The flume walls were made of transparent glass, and thus the water surface profile and flow conditions were observable. To make the tests results accurate, the flume was checked in terms of sealing and any probable cracks in its edges. Specifications of different parts of the flume and laboratory equipment used in this study are as follows (Figure 3).

A groundwater storage tank, a digital flow meter for measuring discharge with an accuracy of $0.2 \mathrm{~L} / \mathrm{s}$, a stilling tank (head tank), and a 3-inch electric submersible pump with a maximum discharge of $120 \mathrm{~m}^{3} / \mathrm{h}$, were the equipment used in the present work. The flume bottom was fixed in a horizontal position, with the bed slope being almost zero. First, the pump discharges the flow from the storage tank to the head tank at flume inlet (flume upstream). The low volume rate of flow slowly discharges in the channel and smoothly flows over the weir installed on the flume bed. Then, the discharge rate is changed to study and record hydraulic conditions of weir discharge. Finally, the water flow enters the pump tank through the downstream channel and returns to the cycle.

In this study, the curved labyrinth and PK weirs were tested at different discharge rates (Figure 4). The weirs used in this research were made of Plexiglas. After the model's dimensions were obtained, the required cuts were made with a laser-cutting machine. Next, different pieces of weir were connected using an appropriate adhesive. Installation of laboratory weir prototypes was carefully done by balancing and waterproofing them with adhesive (Figure 4). In all experiments, the upstream and downstream beds were equally balanced. In addition, the width of discharge channel amounted to $30 \mathrm{~cm}$, and w/p ratios of 2 , 2.5 , and 3 were adopted. The thickness $(\mathrm{t})$ and apex diameter (A) of labyrinth weir with curved planform amounted to $5 \mathrm{~mm}$ and $3.5 \mathrm{~cm}$, respectively. For highly accurate determination of $\mathrm{Ho} / \mathrm{P}$ effect on the performance of investigated weirs, 12 flows with rates varying from 5 to $100 \mathrm{~m}^{3} / \mathrm{h}$ (before submergence to submergence and after submergence) with different hydraulic loadings were applied to each weir. It can be noted that submergence refers to the situation in which the downstream flow depth exceeds crest elevation [17]. According to the studies, the effect of submerged labyrinth weirs is similar to that of linear weirs where, if the downstream water depth does not exceed the crest elevation, it will have no impact on the performance of weir. In other words, the discharge rate starts decreasing only if the tailwater depth exceeds crest elevation. It is worth mentioning that the use of labyrinth weirs is not recommended under extreme submergence [18]. In a study conducted on fuse gates, Falvey and Trail (1995) reported similar results [19]. In addition, Hay and Taylor (1970) disapproved the use of labyrinth weirs under extreme submergence.

The complexity of flow pattern and the effect of different and uncertain factors on the hydraulic characteristics of labyrinth 
weirs have caused the vast use of physical models in the study, design and use of such weirs. The efficacy of discharge capacity is expected to change in labyrinth weirs with geometric fluctuations over their length. However, due to flow interference, the discharge coefficient is smaller in labyrinth weirs than in linear weirs, over the same length [3].

The geometric and hydraulic specifications of examined weirs are presented in Tables 1 and 2.

In the above tables, $w(\mathrm{~cm}), P(\mathrm{~cm}), \mathrm{L}(\mathrm{cm}), T(\mathrm{~mm})$, and $\mathrm{N}$, stand for cycle width, weir height, effective weir length, weir thickness, and cycle number in the weir, respectively.
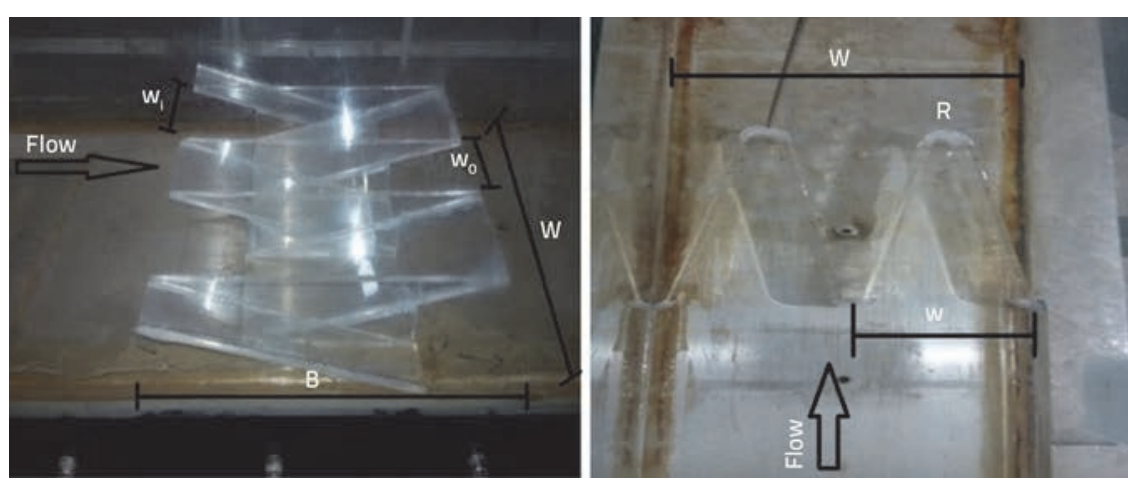

Figure 4. Installation of curved planform weir and PKW in a laboratory flume

Table 1. Geometric and hydraulic specification of PK weirs

\begin{tabular}{|c|c|c|c|c|c|c|c|}
\hline Model & $\begin{array}{c}\mathbf{W} \\
{[\mathrm{cm}]}\end{array}$ & $\mathbf{w / p}$ & $\begin{array}{c}\mathbf{L} \\
{[\mathrm{cm}]}\end{array}$ & $\begin{array}{c}\mathbf{T} \\
[\mathrm{mm}])\end{array}$ & $\mathbf{N}$ & $\mathbf{W}_{\mathbf{i}} / \mathbf{W}_{\mathbf{o}}$ & $\begin{array}{c}\text { Test } \\
\text { number }\end{array}$ \\
\hline PKW & 15 & $\begin{array}{c}2,2,5 \\
\text { and 3 }\end{array}$ & 136 & 5 & 2 & 1.25 & 36 \\
\hline
\end{tabular}

Table 2. Geometric and hydraulic specification of 2-cycle curved labyrinth weir

\begin{tabular}{|c|c|c|c|c|c|c|c|}
\hline Model & $\begin{array}{c}\mathbf{W} \\
{[\mathrm{cm}]}\end{array}$ & $\mathbf{w / p}$ & $\begin{array}{c}\mathbf{L} \\
{[\mathrm{cm}]}\end{array}$ & $\begin{array}{c}\mathbf{T} \\
{[\mathrm{mm}]}\end{array}$ & $\mathbf{N}$ & $\begin{array}{c}\text { Weir } \\
\text { planform }\end{array}$ & $\begin{array}{c}\text { Test } \\
\text { number }\end{array}$ \\
\hline Curved & 15 & $\begin{array}{c}2,2.5 \\
\text { and 3 }\end{array}$ & 143 & 5 & 2 & 2-cycle curve & 36 \\
\hline
\end{tabular}

\section{Results and discussion}

\subsection{Discharge coefficient in curved planform and PK weirs under influence of weir height}

Rectangular, triangular, trapezoidal, and curved labyrinth weirs rank among efficient structures for flow regulation and discharge within limited width. In addition, PK weirs are a new type of weirs with a very high discharge capacity. They are very economical and efficient structures. In this study, the performance of the curved planform labyrinth weir was compared in laboratory conditions with that of the PK weir. It is worth noting that both $\mathrm{PK}$ and curved planform weirs investigated in this paper had two cycles. The comparison suggests that the discharge coefficient increases to its maximum level in all investigated cases.

Also, by increasing the hydraulic load to approximately $0.2(\mathrm{Ho} / \mathrm{P}=0.20)$, the discharge coefficient increases and reaches its maximum limit, and then decreases. Moreover, according to the results of this study, the highest discharge coefficient is observed in the low hydraulic load ratios of both weirs. As shown in Figure 5, in the PKW the discharge coefficient increases by approximately $26 \%$ after the 50 $\%$ increase in weir height (p) from $5 \mathrm{~cm}$ to $7.5 \mathrm{~cm}(\mathrm{w} / \mathrm{p}=3$ to $w / p=2)$. In comparison, in the curved planform weir, the discharge coefficient increases by approximately $27.1 \%$ after the $50 \%$ increase in weir height from $5 \mathrm{~cm}$ to $7.5 \mathrm{~cm} \mathrm{(w/p} \mathrm{=} 3$ to $\mathrm{w} / \mathrm{p}$ $=2$ ).

The results of the present work are in agreement with those of Haidarpour et
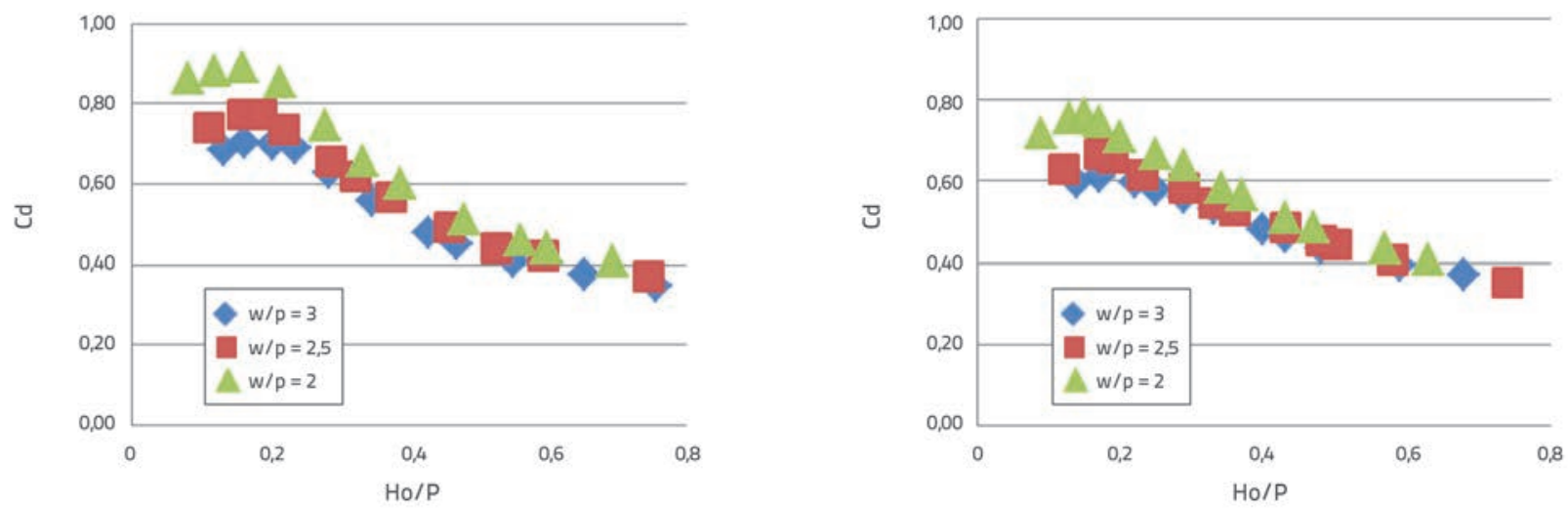

Figure 5. Hydraulic head effects on discharge coefficient in Curved Planform (left) and PKW weirs (right) 

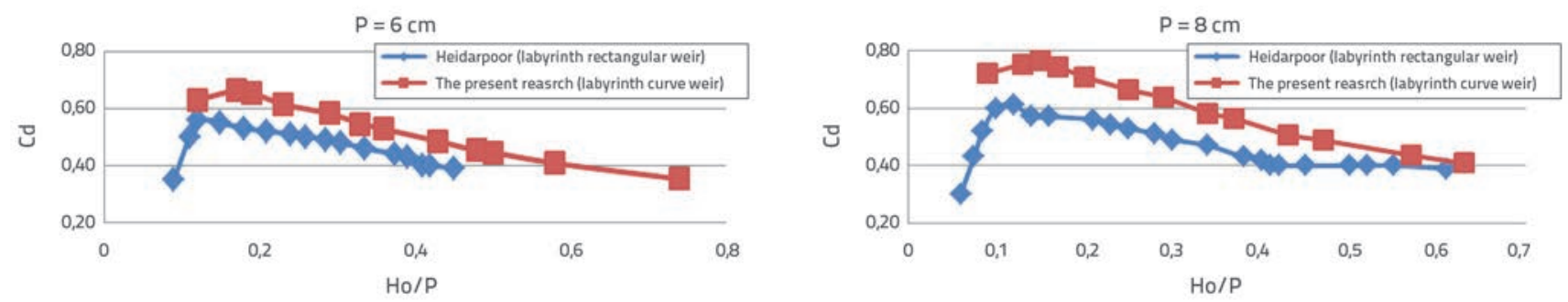

Figure 6. Comparison of discharge coefficient variations of curved planform labyrinth weir (current study) with rectangular plan labyrinth weir for different heights (Heidarpour, [14])

al. (2006) who studied the discharge coefficient in labyrinth weirs (with a rectangular and U-shaped cycle in plan) [14]. The results of experiments showed that the discharge coefficient increases in a certain HO/P with an increase in height of the weir.

The results of this study are compared with those obtained by Heidarpour in Figure 6 [14].

In both curved planform and PK weirs, the effect of weir height on discharge coefficient decreases when approaching the submerged discharge (which occurs when the water head in downstream is equal to weir head). In this situation, in the post-submerged discharge, the weir height increase does not have a considerable impact on discharge coefficient.

Tullis et al. [18] showed that the submergence effect of labyrinth weirs is similar to that of linear weirs. Insofar as the water depth in downstream does not exceed the crested head (submerged discharge), it will have no impact on the weir performance. In other words, the discharge rate decreases only when the tailwater depth exceeds the crest head. It should be noted that the use of labyrinth weirs is not recommended in extreme submergence conditions. Hay and Taylor [3] also disapprove of the application of such weirs in extreme submergence conditions. The submergence thresholds in $\mathrm{PK}$ and curved planform weirs occurred in the $\mathrm{Ho} / \mathrm{P}>0.54$ and $\mathrm{Ho} / \mathrm{P}>0.48$, respectively $(\mathrm{HO}=$ head over the weir, and $\mathrm{P}=$ weir head).

According to Figure 7, the maximum discharge coefficient (almost 0.88 ) occurred in $\mathrm{PK}$ weir in the $\mathrm{Ho} / \mathrm{P}=0.2$ (hydraulic loading ratio) and $\mathrm{w} / \mathrm{p}=2$ (cycle width to weir height). In addition, the maximum discharge coefficient in curved planform weir (almost 0.76 ) occurred in $\mathrm{Ho} / \mathrm{P}=0.17$ and $w / p=2$. In both weirs, the discharge coefficient increases with an increase in the weir height ratio. In addition, in both weir types, when increasing the hydraulic load, the discharge coefficient first increases and then decreases, and reaches its minimum value in the submerged discharge. At such a value, the discharge coefficient has an ascending trend in $\mathrm{PK}$ weir in hydraulic loading ratios $<0.2$ and reaches its maximum amount, and starts decreasing thereafter. In the curved planform weir, the discharge coefficient is ascending in hydraulic loading ratios $<0.16$, after which it follows a descending trend.

The results obtained in this part are consistent with the findings of Crookston and Tullis, who reported that the discharge coefficient is larger than linear weir at low discharge rates, due to the small nappe interference, and the interference gradually becomes extreme with an increase in discharge. As a result, the discharge coefficient reduces to an amount similar to the discharge coefficient in broad-crested weirs $[8,9]$.

\subsection{Comparison of coefficient of discharge $\left(C_{d}\right)$ in curved planform and PK weirs under effect of different hydraulic conditions}

To study the discharge coefficient in both PK and curved planform weirs, three prototypes of each weir type were built with different heights and compared in equal elevation ratios. Their cycle width (w), cycle number (N), and weir heights were taken to be $15 \mathrm{~cm}, 2$, and $5,6,7.5 \mathrm{~cm}(\mathrm{w} / \mathrm{p}=2,2.5$, and 3$)$, respectively. The comparison of discharge coefficient in the curved planform and PK weirs in different height conditions is shown in Figure 7.

As can be seen from Figure 7, the discharge coefficient is significantly greater in PKW than the curved planform weir, insofar as this difference is big at low hydraulic load. However, it gradually reduces with an increase in hydraulic load and with an approach to submerged discharge, which is a value where the water depth in weir downstream and weir head are equal. It should be noticed that in submerged discharge, and postsubmerged discharge, both weirs function as a barrier to the flow; therefore, the discharge coefficients would be equal in them.

It can be seen that, for hydraulic load values of about $0.2(\mathrm{Ho} / \mathrm{P}$ $=0.2$ ), the discharge coefficient in PKW is almost $15.2 \%$ bigger than that of the curved planform weir in the ratio of $w / p=3$. This difference decreases with an increase in hydraulic load. In addition, the discharge coefficients of both weirs become almost equal in submerged and post-submerged discharges. Similarly, in hydraulic load values of about $0.2(\mathrm{Ho} / \mathrm{P}=0.2)$, the discharge coefficient in PK weir is almost $16.4 \%$ bigger than that of the curved planform weir in the ratio of $w / p=$ 2.5. This difference decreases with an increase in hydraulic load. In addition, the discharge coefficients of both weirs are equal in submerged and post-submerged discharges. 

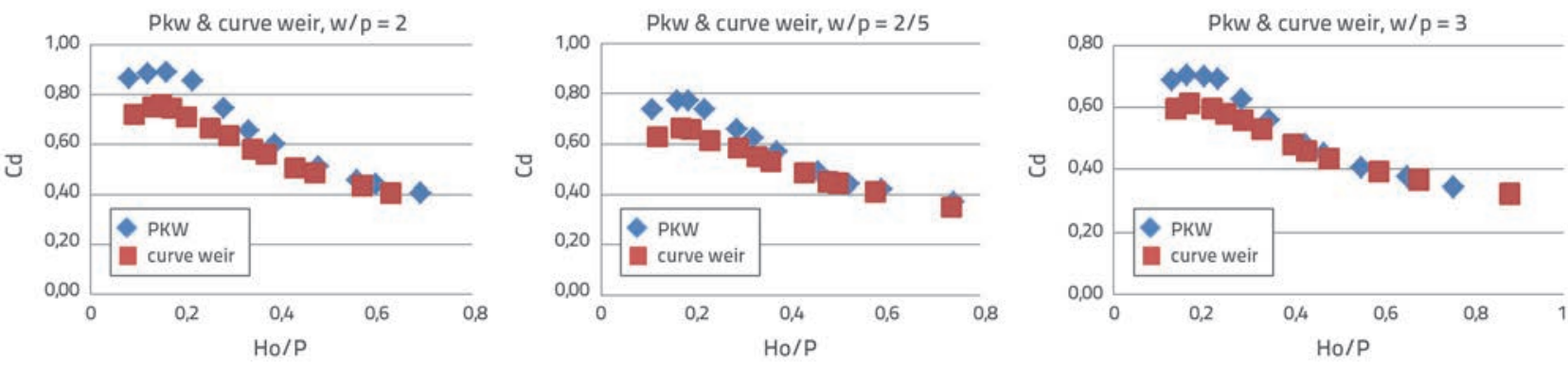

Figure 7. Discharge coefficient in curved planform and PK weirs in different height ratios

Similarly, in hydraulic load values of about $0.2(\mathrm{Ho} / \mathrm{P}=0.2)$, the discharge coefficient in $\mathrm{PK}$ weir is almost $17.1 \%$ bigger than that of the curved planform weir in the ratio of $w / p=2$. This difference decreases with an increase in hydraulic load. In addition, the discharge coefficients of both weirs are equal in submerged and post-submerged discharges.

Accordingly, it can be concluded that the percentage of increase in discharge coefficient is greater in PKW than curved planform weir with an increase in weir height.

Anderson and Tullis [11] studied performance of PKW and concluded that the discharge coefficient increased with an increase in Wi/Wo ratio (the width of the inlet to outlet key).

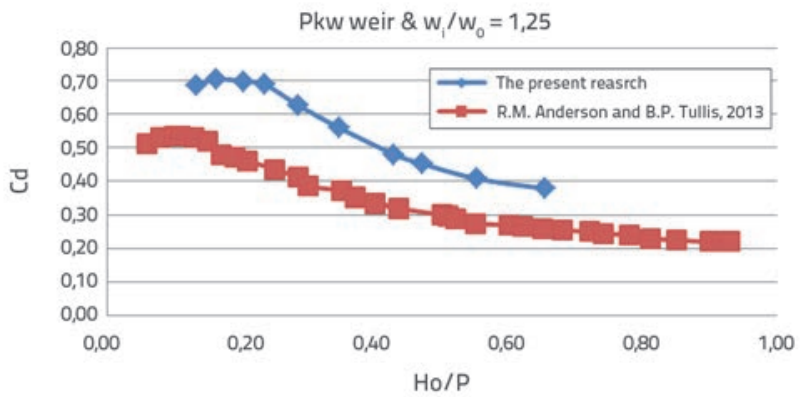

Figure 8. Discharge coefficient with Ho/P in PKW in the present study compared with results from [11]

Figure 8 compares the results of this study with those obtained by Anderson and Tullis (PKW with Wi/Wo $=1.25$ ). In this figure,
$\mathrm{Cd}, \mathrm{Ho}$, and $\mathrm{P}$ are the discharge coefficient, the height of water on the weir, and the height of weir, respectively.

\section{Conclusion}

The comparison of the piano key weir (PKW) and the curved planform weir suggests that the discharge coefficient is bigger in all pre-submerged discharge conditions in PKW compared to the curved planform weir. In this regard, the biggest difference was observed at $w / p=2$, where the discharge coefficient was by 17.1 $\%$ bigger in PKW than in the curved planform weir. The difference in the discharge coefficient decreases in both weirs with an increase in the $w / p$ ratio (weir height reduction). This increase is greater at lower hydraulic loads, but it decreases when approaching the submerged discharge value. In addition, the discharge coefficients of both weirs become almost equal at submerged and postsubmerged discharge values. Moreover, a $50 \%$ increase in the PKW height (from 5 to $7.5 \mathrm{~cm}$ ) increases the discharge coefficient by 26 $\%$. As to the curved planform weir, a $50 \%$ increase in weir height increased the discharge coefficient by $27.1 \%$.

\section{Acknowledgment}

The authors of this article would especially like to thank the Educational Complex of Water and Electricity Organization of Khuzestan for providing them with the laboratory flume and equipment. In addition, thanks are also extended to Dr. Moradi and Mr. Amiri for providing the authors with their guidance.

\section{REFERENCES}

[1] Falvey, H.T.: Hydraulic Design of labyrinth weirs. ASCE Press, USA. 2003

[2] Crookston, B.M., Tullis, B.P.: Discharge efficiency of reservoir application specific labyrinth weirs. J.Irrig. Drain. Engr. ASCE. 2012b, 138 (2012) 6, pp. 773-776.

[3] Hay, N., Taylor, G.: Performance and design of labyrinth weirs. J. Hyd. Div., ASCE, 96 (1970) 2, pp. 2337-2357.

[4] Laugier, F.: Design and construction of the first Piano Key Weir (PKW) spillway at the Goulours dam, Hydropower and Dams, 13 (2007) 5, pp. 94-101.
[5] Ouamane, A., Lempérière, F.: Design of a new economic shape of weir, in proc. of International Symposium on Dams in the Societies of the 21st Century. Barcelona, Spain, pp. 463-470, 2006.

[6] Leite Ribeiro, M., Pfister, M., Boillat, J.L., Schleiss, A.J., Laugier, F.: Piano key weirs as efficient spillway structure, $24^{\text {th }}$ ICOLD Congress on Large Dams, Kyoto (J), Q.94-R.13, 2012.

[7] Machiels, O.: Experimental study of the hydraulic behaviour of Piano Key Weirs, Ph.D. Thesis ULgetd-09252012-224610, University of Liège (B), 2012. 
[8] Crookston, B.M., Tullis, B.P.: Arced labyrinth weirs. J. of Hydraul. Eng. ASCE, 138 (2012c) 6, pp. 555-562.

[9] Crookston, B.M., Tullis, B.P.: Labyrinth weirs: nappe interference and local submergence. J. Irrig. Drain Eng. ASCE, 138 (2012d) 8, pp. 757-765.

[10] Anderson, R.M., Tullis, B.: Comparison of Piano Key and Rectangular labyrinth weir hydraulics, Journal of Hydraulic Engineering, 138 (2012) 4, pp. 358-361.

[11] Anderson, R.M., Tullis, B.: Piano Key Weir Hydraulics and labyrinth weir Comparison, Journal of Irrigation And Drainage Engineering. ASCE, pp. 246-253, 2013, https://doi.org/10.1061/(ASCE) IR. 1943-4774.0000530

[12] Javaheri, A., Kabirisamani, A.: Determination of PKW discharge coefficient in free flow condition. The first International Conference and the Third National Conference on Dam and Hydroelectric Plants, Tehran, pp. 1-8, 2011. [in Persian]

[13] Karimi-Chahartaghi, M., Nazari, S., Karimi-Chahartaghi, M.: Laboratory study into discharge coefficient in PKW with variable crest. Eighth National Congress of Civil Engineering, Babol, Noshirvani University of Technology, pp.1-7, 2014. [in Persian]
[14] Heidarpoor, M., Mousavi, F., Roshani-Zarmehri, A.R.: Labyrinth weirs with rectangular and U-shape planforms. Journal of Agricultural Sciences and Natural Resources, Isfahan University of Technology, 10 (2006) 3A, pp.1-11. [in Persian]

[15] Crookston, B.M.: Labyrinth weirs, Ph.D. Thesis, Utah State Univ., Logan, UT. 2010

[16] Tullis, P., Amanian, N., Waldron, D.: Design of labyrinth weir spillways. J. Hydraul. Eng. ASCE, 121 (1995) 3, pp. 247-255.

[17] Villemonte, J.R.: Submerged weir discharge studies, Engineering News Record, 139 (1947) 26, pp. 54-56.

[18] Tullis, B., Young, J., Chandler, M.: Head-Discharge Relationships for Submerged labyrinth weirs. J. Hydraul. Eng., 133 (2007) 3, pp. 248-254.

[19] Falvey, T.H., Treille, P.: Hydraulics and design of fuse gates, J. of Hydr. Engrg., ASCE, 121 (1995) 7, pp. 512-518. 